\title{
Feasibility study of AL-Masab AL-Aam water drainage in ThiQar and treatment for irrigation
}

\author{
Kadhim Naief Kadhim, Abbas Yasir Hussein \\ College of Engineering, University of Babylon-Iraq \\ Email address: \\ altaee_kadhim@yahoo.com(K. N. Kadhim), aljawei@yahoo.com(A. Y. Hussein)
}

\section{To cite this article:}

Kadhim Naief Kadhim, Abbas Yasir Hussein. Feasibility Study of AL-Masab AL-Aam Water Drainage in ThiQar and Treatment for Irrigation. Journal of Water Resources and Ocean Science. Vol. 2, No. 5, 2013, pp. 84-89. doi: 10.11648/j.wros.20130205.15

\begin{abstract}
The Irrigation sector in different part of world including Iraq is a major water consumer to produce adequate food for increasing high population growth and meeting the MGD food goal. The challenges for the Iraq agriculture sector are to increase food production through effective management of the available and potential water sources including drainage and treated waste water and at the same time conserve and protect its environmental.(Ayers, R. S., and D. W. Westcot. (1985). In Iraq, the water users in different districts and policy makers are showing increasing interest in increasing the reuse drainage water as means of augmenting dwindling useable water supplies. Waterhowever its quality must meet crop tolerance to achieve optimal production and reduce environmental impact. To evaluate feasible option this study is concerned with assessing the suitability of drainage water of Al-Masab Al-Aamlocated for irrigation with or without treatment. Al-Masb Al-Aam drainage passes through the territory of governorate of ThiQar for part of the course covering $180 \mathrm{~km}$ out of the $565 \mathrm{~km}$ and the discharge of the total $220 \mathrm{~m} 3$ /. The approach is to evaluate the chemical and physical properties of drainage water from the nearby irrigated field and and the water of Al Gharraf river in the Al-Fajr city northern of Nassiriyah, and the water of the Euphrates River south of Nassiriyah. The drainage water was to be blend fresh water of the nearest river through revaluating different ratios of blending starting with R1 which represents $90 \%$ drainage water blended with $10 \%$ river water, R2 ( with $80 \%$ drainage water and $20 \%$ river water andand followed by blending ration up (R3 - R9)to nine trials. Monthly water samples were taken from four locations: two from drainagewater and two from rivers over the period from June 2011, to July 2012.Physically and chemically analyzed for EC,TDS, PH, $\mathrm{Ca}++, \mathrm{Mg}++, \mathrm{Na}+$, $\mathrm{K}+$, $\mathrm{Cl}-$, SO4, NO3 , Turb. , PO4 and T.Hwere carried out on 48 samples. The analyses indicated that the Sodium Adsorption Ratio (SAR) for drainage water was less than 12, which is acceptable for irrigation use. In terms of salinity, the drainage water of Al-Masab Al-Aam its acceptable for irrigation because the halophytes can be irrigated with EC) less than 8000 Micro Siemens/cm. The blending between the drainage water and the fresh water of $\mathrm{Al} \mathrm{Gharraf} \mathrm{river}$ showed showed god blending ratio (R7) having the EC) less than 3000 Micro Siemens/cm.
\end{abstract}

Keywords: Drainage, Water, Blending, Almasab Al-Aam

\section{Introduction}

The world's irrigated area is currently estimated to be 260-270 million hectares. The past averaged annual growth was estimated $2 \%$ and has fallen to less than $1 \%$. While only about 17 percent of the world's cultivated land is irrigated, it produces one-third of the world's fresh food harvest and about half of its wheat and rice production. It is predicted that at least half of the required increase in food production in the near-future decades must come from the world's irrigated land. In view of the role of irrigated agriculture as the "world's food machine", competition for water cannot be allowed to result in even lower food production growth rates, or an absolute reduction, of the world's irrigated area. The challenge is therefore clearly to produce more food by enhance management measures and none conventional sources such as drainage and adequately treated wastewater source.(FAO. (1992)).

The most feasible options to meet the challenge to enhance the fresh water management are to reduce the amount of irrigation water applied and to reuse the nonconsumed fraction of the irrigation water already diverted. It is well documented (Hill 1994; Frederiksen 1992) that, at the field level, a large part (typically half) of the applied irrigation water is not actually consumed by a given crop and therefore ends up as drainage water. Since much of the 
drainage water commonly becomes the source of the water for downstream irrigation schemes and for other uses, the water use efficiency computed at the basin level is usually much higher than it is at the field or irrigation scheme level. In many irrigated areas, however, there is ample scope for planned reuse of drainage water supported by increasing interest of decision makers and water users and both water users as means of augmenting dwindling useable water supplies.(Gupta, I.C.1979.)

\section{Study Area}

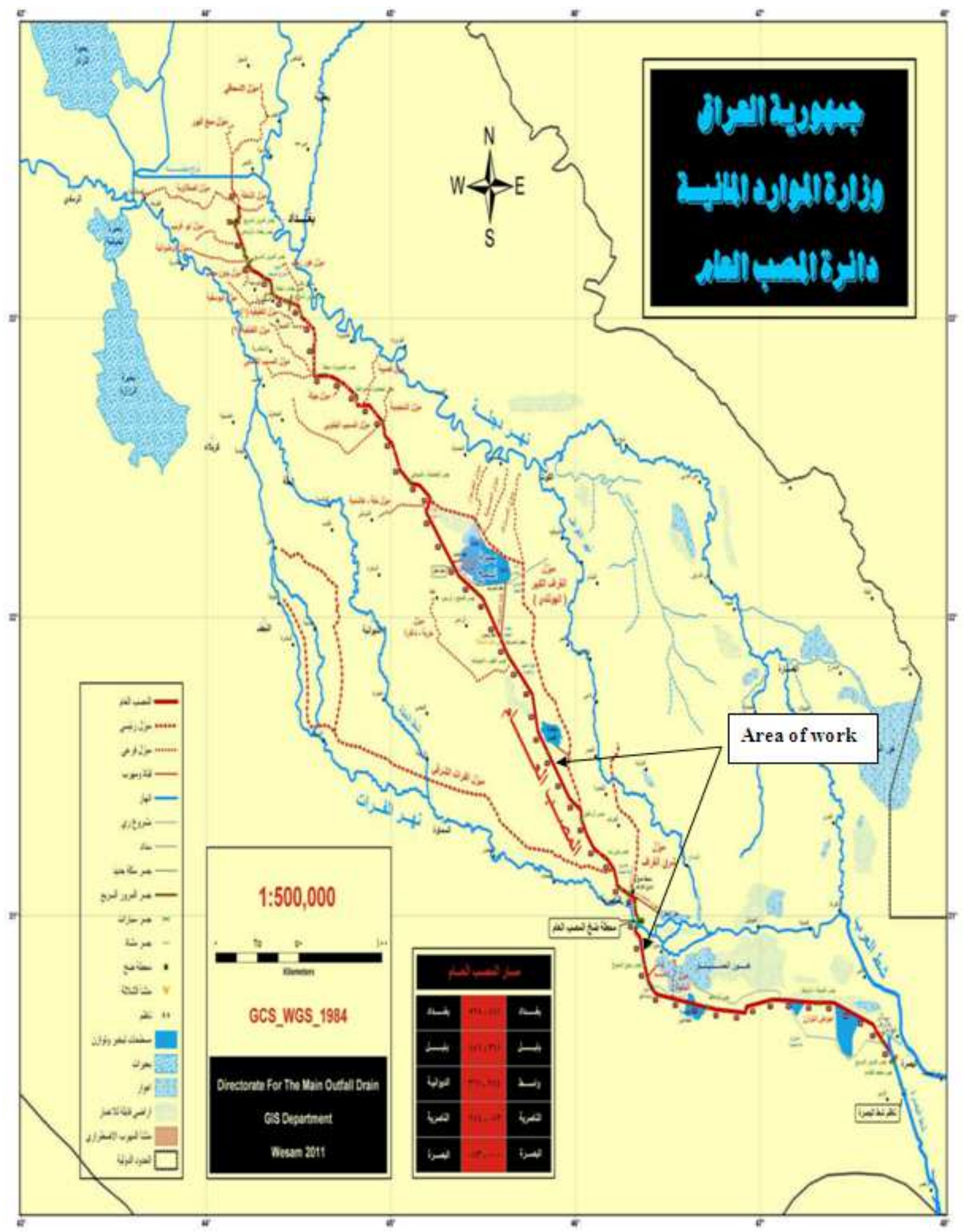

Fig (1): AL-Masb AL-Aam map (Fahad K. 2006) 
The project Al-masab Al-aamis one of the major development projects in Iraq aimed at removing salt water collected from the reclamation lands in the central and southern Iraq byinterconnected drainage network. The idea of setting up AL-masabALaam came in the Fifties, when a U.S. company worked to prepare a map of networks drainages between the rivers Tigris and Euphrates.Al-Masb Al-Aam shown in Figure (1) passes through the territory of governorate of ThiQar for part of its $180 \mathrm{~km}$ course out of the total length of the project, which has $565 \mathrm{~km}$ with a discharge of the total $220 \mathrm{~m} 3 / \mathrm{s}$ and the project consists of several important stages in the operation, including within the boundaries of the province of ThiQar is Home drainages estuaries.

Al-masab AL-aamdrainage networks transfer saline water though the project to the Arabian Gulf through the Home of its parts (North and East andSouth. The first phase of the project started in 1973 followed by implementation of different phases and completed on December, 12,2008 by installation of the main pumping station south of Nasiriyah at longitude (30 58'09") north and latitude $\left(46^{\circ} 20^{\prime} 38^{\prime \prime}\right)$ east with the discharge capacity of $220 \mathrm{~m} 3$ per second.
The Project area is influenced by the prevailing climatic regime and soil characteristics in relation to crops productions. The climatic condition crop impact influence the yield, the surrounding the process of agricultural production such as soil and water resources, and includes the activity of workers in agriculture and vitality.

The most dominate climatic factor is the rainfall region as influence soil moisture availability and water renewability in relation to the irrigation water requirement. The rainfall regime at the ThiQar Governorate located within the dry region has average rainfall depth of 127.48 $\mathrm{mm}$ estimated for the period 1970-2010(Ministry of Science and Technology, General Authority, Climate Division). The rainfall regime is influence by the Mediterranean circulation system due toair depressions and erosion from travelling long distances and the high atmospheric air above the Arabian Peninsula during the cold season of the year. There by preventing the incursion Mediterranean depressions towards the study area, reflecting the seasonality of the rainfall regime, Only where they hit the cold season, despite falling rates very few almost negligible in the months of June and September as shown in table (1)

Table(1): Average 40 years monthly and annual rainfall depth (mm) at DhiQar, for the period (1970-2010) (Najim A.R. 2007)

\begin{tabular}{lccccccccccccc}
\hline Month & Jan & Feb & Mar & Apr & May & Jun & Jul & Aug & Sep & Oct & Nov & Dec & Tot \\
\hline Depth(mm) & 29.2 & 19.2 & 20.9 & 10.5 & 5.0 & 0.2 & - & - & 0.8 & 5.6 & 15 & 21.2 & 127.6 \\
\hline
\end{tabular}

The rainfall distribution varied low value of $0.19 \mathrm{~mm}$ in June to high value of $29.17 \mathrm{~mm}$ in January as shown in table (1) data starts with the beginning of September $(0.83$ $\mathrm{mm}$ ), after which rainfall increases to the maximum amountin the month of January $(29.17 \mathrm{~mm})$. This means that $(90.9 \%)$ of the total amount of rainfall took place from November-April.In addition, the amount of rainfall is erratic and irregular due to its location within the desert region. The small amount of rain, the irregular distribution of the rainy season months and the large annual fluctuations, are problems reflected in the lack of reliability in agriculture whichmakes farming in the governorate mainly dependent on the process of irrigation.

The other influencing factor is the soil characteristics. The soil is of gypsum type in parts of the western areas, and desert sand and gravel in the south western parts are generally loose soils where erosion is active because of the scarcity of natural vegetation and drought. Analysis results showed that the physical and chemical content of the soils were clay, silt and sand (9.2\%) (5.7\%) (85.1\%), respectively. According to triangle tissues soil are sandy soils this mix of rough tissue. Either density virtual reached (1.67 g / cm3).(Al-Zubaidy A. 1990 \& Al-Dooryetc 1989)

The average soil properties were estimated for; theporosity (36\%), while ,moisture content at field capacity (11\%),organic matter $(0.2 \%)$ gypsum $(4.18 \%)$ and lime $(11.9 \%)$ while for the $(\mathrm{PH})$ at $(7.7)$. he soil types are suitable for growing of variety of crops specially vegetables in Um eenayj) and Al-Gabeshiah. The soil types variability in the governorate of ThiQar has provided option of diverse of crops production and favorable environmental conditions has enhanced its potential development for various farming practices. (Fahad K. 2006).

\section{Methodology}

The analysis was implemented through determiningthe physical and chemical content of the collected water samples from from a number of points along the study areas. Water samples were collected from the surface layer of the river (30) $\mathrm{cm}$ from the top, and bottles made ofWater was collected in 5 liters capacity polyethylene bottles with the Nozzles closed tightly to prevent the entry of air after it has been homogenized. Drainage samples were collected from 4 collection points. The collection points samplingto estimate the Electrical conductivity (EC) were at; near the main pump station of AL-Masab AL-Aam southern of Nassiriyah designated by the simple D1, the AL-Fajr city northern of AL-Nassiriyah as D2, for Euphrates river in the point near the main pump station of AL-Masab AL-Aam southern of Nassiriyah as $\mathrm{C} 1$ and AL-Gharraf river in the AL-Fajr city northern of AL-Nassiriyah as C2.

The monthly sampling was one sample per station 
covering the period July 2011 to June 2012.The physical analyses focused on estimating Total Dissolved Solids,Temperature,Turbidity and Electrical Conductivity while the chemical analysis covered $\mathrm{pH}$, Nitrate, Phosphate, Total Hardness, Potassium, Sulfate, Calcium, Magnesium, Chloride, and Sodium. The water sample of drainage water blending with water of nearest river with different ratios is shown in table (2)

Table (2): Blending ratio percentage \% of the drainage and river water

\begin{tabular}{lll}
\hline $\begin{array}{l}\text { Blending } \\
\text { ratio }\end{array}$ & $\begin{array}{l}\text { Drainage } \\
\text { water \% }\end{array}$ & $\begin{array}{l}\text { River } \\
\text { water } \%\end{array}$ \\
\hline R1 & 90 & 10 \\
R2 & 80 & 20 \\
R3 & 70 & 30 \\
R4 & 60 & 40 \\
R5 & 50 & 50 \\
R6 & 40 & 60 \\
R7 & 30 & 70 \\
R8 & 20 & 80 \\
R9 & 10 & 90 \\
\hline
\end{tabular}

\section{Discussion}

The analyses of the Electrical conductivity at the 4 observation points (EC) ranged from 6500 to 8000 Micro Siemens $/ \mathrm{cm}$.Higher and almost identical values were observed at two reaches D1 and D2 at near the main pump station of AL-Masab AL-Aam southern of Nassiriyah and the AL-Fajr city northern of AL-Nassiriyah The lowest values of 1000 was at point $\mathrm{C} 2$ for AL-Gharraf river in the AL-Fajr city northern of AL-Nassiriyah as shown in figure (2). Low monthly values were observed during the month November for D1.D2 and C1. The high EC values indicate the salt content at these reaches. In case of salinity, the (EC) results showed for ALMasab AL-Aam water drainage a range between 6000 and 8000 Micro Siemens $/ \mathrm{cm}$. Thus it can be used for irrigating Eucalyptus, date-palm, barely, wheat (semi-dwarf) and cotton.(AbawiS.and Hassan M.1990 \&Al-MosawiA.1977)

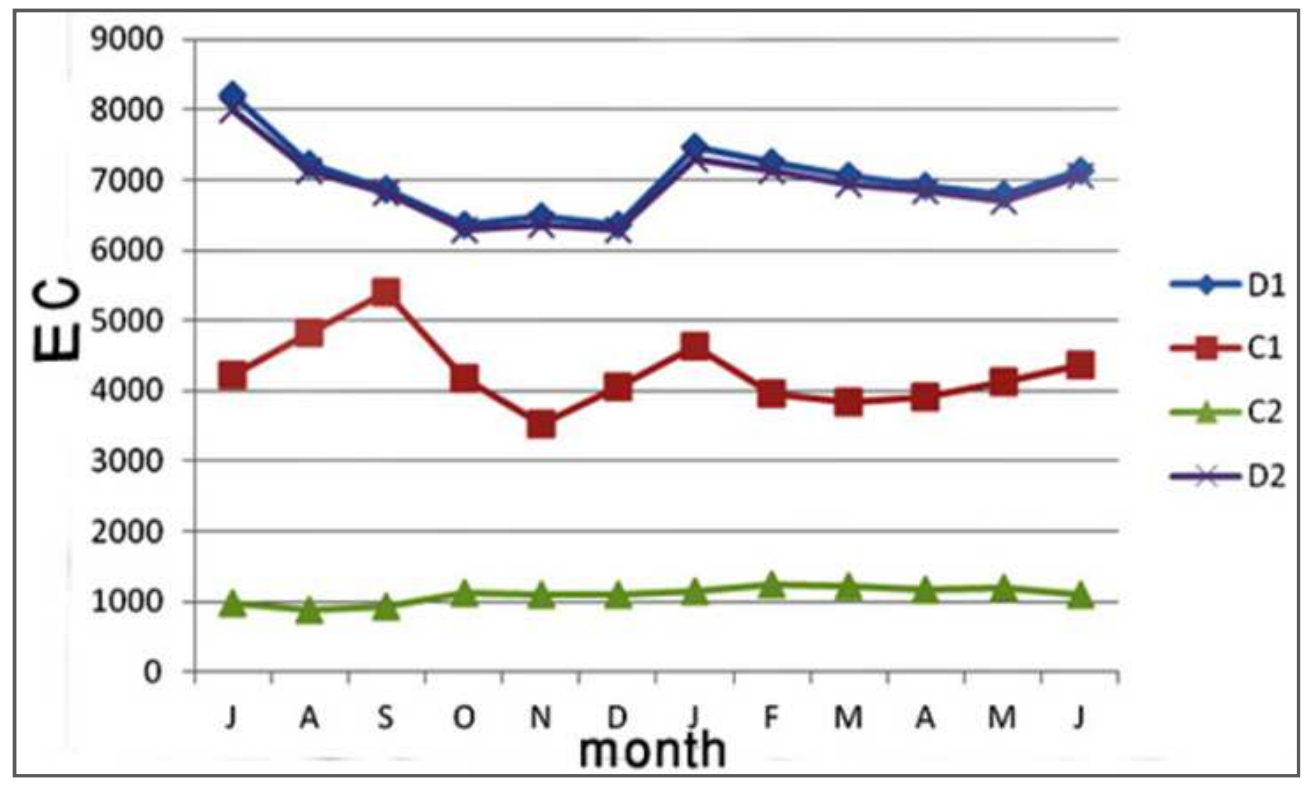

Fig.(2):Variation of the Electrical conductivity at the 4 observation points (C1,C2, D1 and D2)

Also analyses of the Sodium Adsorption Ratio (SAR) at C1 , C2 , D1 and D2 as was done of the Electric Conductively as shown in figure(3). The SAR values ranged from 2.5 to 13 with the higher values at point D1 near the main pump station of AL-Masab AL-Aam southern of nassiriyah, D2 at the AL-Fajr city northern of ALNassiriyah . The result of testing showed that the (SAR) value for the Euphrates is between 6.89 and 11.2, for AL-

Garraf river it is between 2.42 and 3.87 and for ALMasab AL-Aam water the value of (SAR) is between 9.16 and 11.92. From the test results and comparison with the U.S. division (1985) we can deduce that the water of these stationsits acceptable for irrigation according to the (SAR) indicator where the (SAR) its less than 12. 


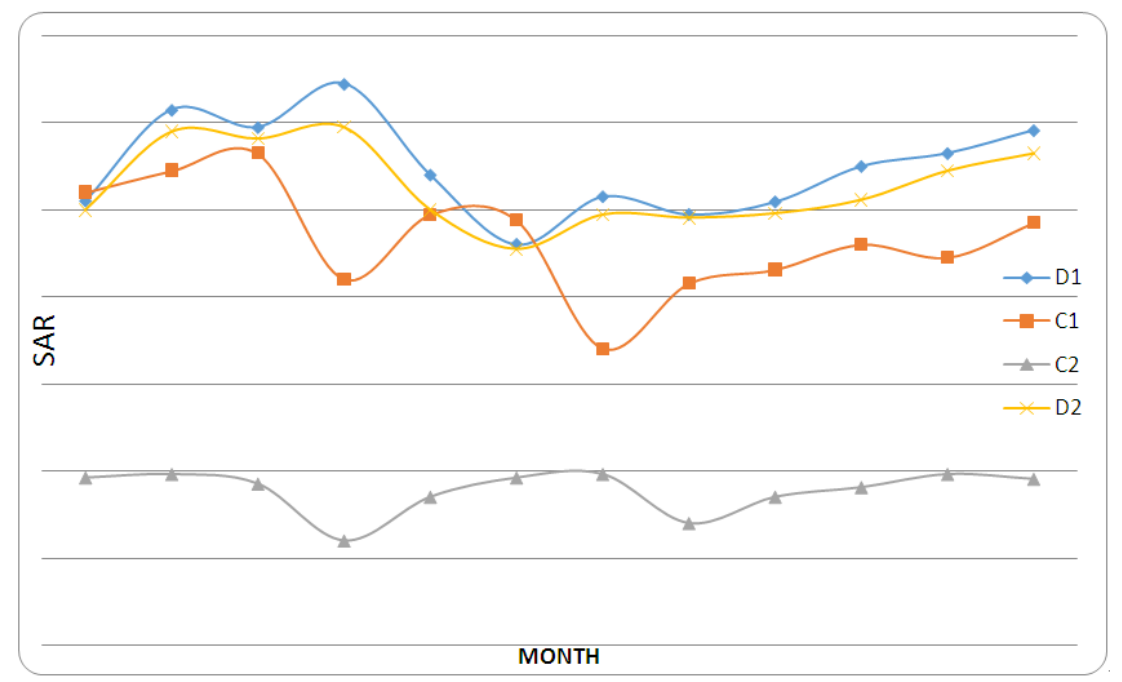

Fig.(3): Variation of the Sodium Adsorption Ratio (SAR) at the 4 observation points (C1,C2, D1 and D2)

Figure (4) shows the monthly results for Electrical conductivity (EC) for each blending ratio between the drainage water of AL-Masab AL-Aam and the water of Euphrates river, in the point near the pump station of AL-Masab ALAamsouthern of niassiriah .

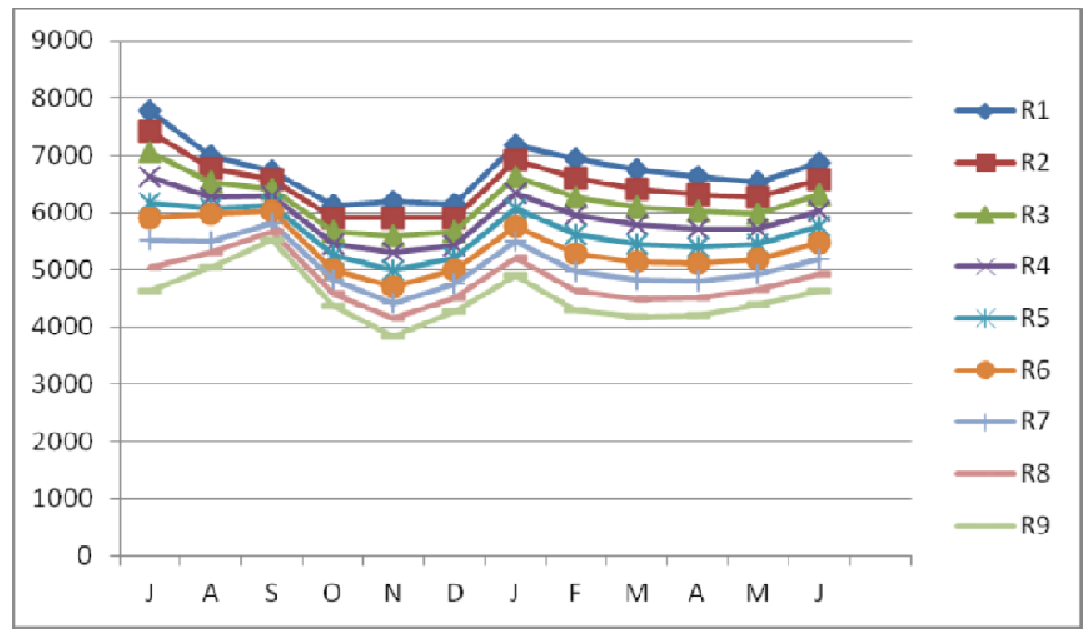

Fig.(4): Variation of Electrical conductivity (EC) for different blending ratio of the drainage water of AL-Masab AL-Aam and the water of Euphrates River.

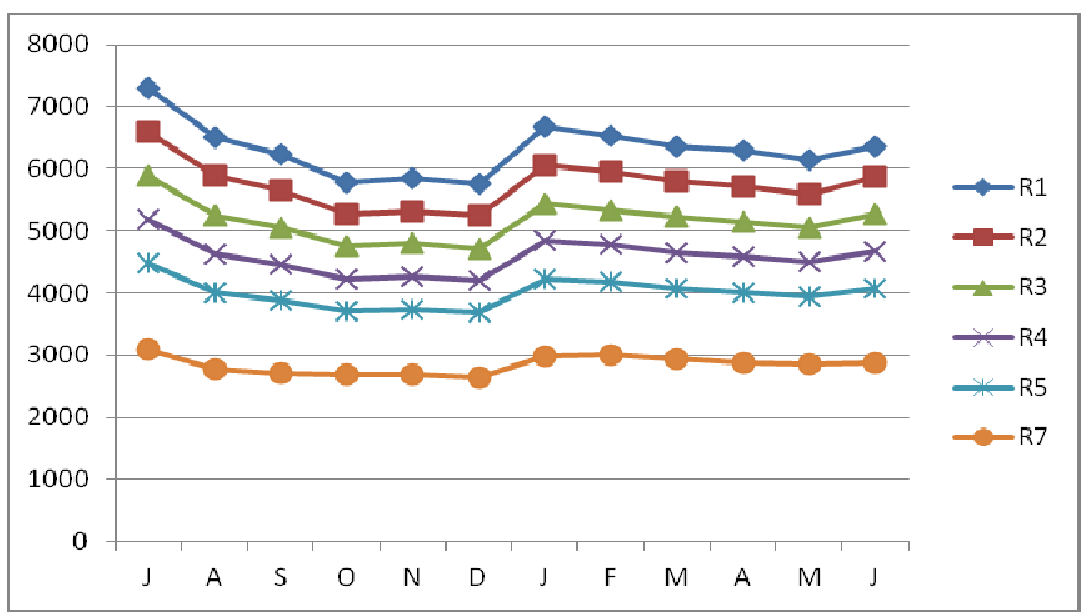

Fig (5): the monthly results for Electrical Conductivity (EC) for each blending ratio between the drainage water of AL-Masab AL-Aam and the water of AL-Gharraf river in AL-Fajr city. 
The blending between the Euphrates river water and ALMasab AL-Aam water showed that for blending ratio (R1) and (R2) it is greater than 6000 and less than $7000(\mu \mathrm{s} / \mathrm{cm})$ so it can be used to irrigate Sorghum. The blending ratio (R4) would work for wheat irrigation and the blending ratio (R7) for Sunflower

The blending ratio between AL-Masab AL-Aam and AL-Garraf river showed that for the blending ratio (R1) the result can used for irrigate Eucalyptus, date-palm ,barely, wheat(semi-dwarf), cotton and sorghum, the blending ratio (R4) for sunflower irrigation, the result of blending ratio (R7) is good water for irrigation with electrical conductivity less than $3000(\mu \mathrm{s} / \mathrm{cm})$

\section{Conclusions}

The conclusions drawn from this study are summarized as follow:

-- The analyses indicated that the Sodium Adsorption Ratio (SAR) for drainage water was less than 12, which is acceptable for irrigation use. In terms of salinity, the drainage water of Al-Masab Al-Aam its acceptable for irrigation because the halophytes can be irrigated with EC) less than 8000 Micro Siemens/cm. The blending between the drainage water and the fresh water of $\mathrm{Al}$ Gharraf river showed showed god blending ratio (R7) having the EC) less than 3000 Micro Siemens/cm.

-- Water from location D1 represents the water of ALMasab Al-Aam water drainage. It may be suitable for growing Date-palm, Barely, and Wheat(semi-dwarf) .

\section{References}

[1] Ayers, R. S., and D. W. Westcot. (1985). Water quality for agriculture. Irrigationanddrainage. No. 29. Roma, Italy. FAO.

[2] Gupta, I.C.1979.Anew classification and evaluation of quality of irrigation water for arid and semi- arid zones of India.Trans. Isdt and Ueds.

[3] FAO. (1992). the use of saline water for crop production. Irrigation and Drainage Papers. No. 48. Rome, Italy.

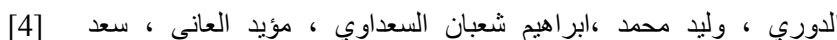

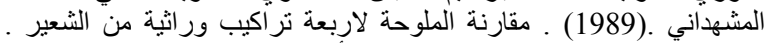
ألمجلة العر اقبة لبحوث علوم الحياة.

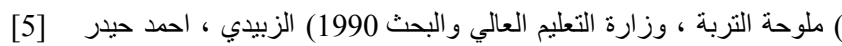
العلمي ، جامعة بغذاد - بيتالحكمة.

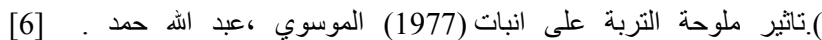

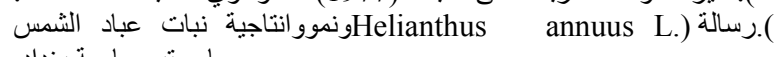

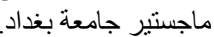

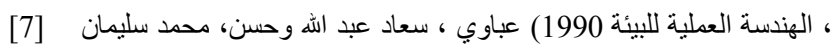
فحوصات الماء، وزارة التعليم العاليو البحث العلمي - جامعة الموصل . لمعل

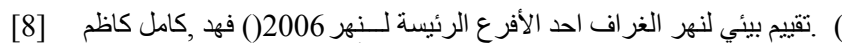

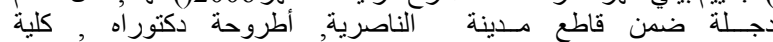

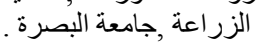

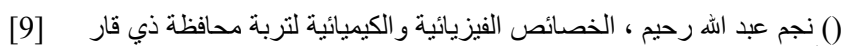

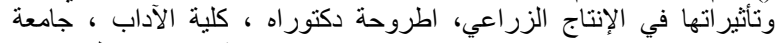

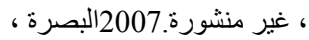

